\title{
Prospects of 3D bioprinting as a possible treatment for cancer cachexia
}

\author{
Mustafa Galib ${ }^{1}$, Yusha Araf ${ }^{2}$, Iftekhar Bin Naser ${ }^{1}$, Salman Khan Promon ${ }^{3, *}$ \\ ${ }^{1}$ Biotechnology Program, Department of Mathematics and Natural Sciences, BRAC University, \\ Dhaka, Bangladesh \\ ${ }^{2}$ Department of Genetic Engineering and Biotechnology, School of Life Sciences, Shahjalal \\ University of Science and Technology, Sylhet, Bangladesh \\ ${ }^{3}$ Department of Life Sciences, School of Environment and Life Sciences, Independent University, \\ Bangladesh (IUB), Bashundhara, Dhaka, Bangladesh
}

*Correspondence: salman.promon@gmail.com

\begin{abstract}
Cancer cachexia is a multifactorial syndrome that is identified by ongoing muscle atrophy, along with functional impairment, anorexia, weakness, fatigue, anemia, reduced tolerance to antitumor treatments. Thus, reducing the patients' quality of life. Cachexia alone causes about $22-25 \%$ of cancer deaths. This review covers the symptoms, mediators, available treatment, and prospects of 3D bioprinting for cancer cachexia. Studies about cachexia have shown several factors that drive this disease - protein breakdown, inflammatory cytokines activation, and mitochondrial alteration. Even with proper nutrition, physical exercises, anti-inflammatory agents, chemotherapy, and grafting attempts, standard treatment has been unsuccessful for cachexia. But the use of 3D bioprinting shows much promise compared to conventional methods by attempting to fabricate 3D constructs mimicking the native muscle tissues. In this review, some 3D bioprinting techniques with their advantages and drawbacks, along with their achievements and challenges in in-vivo applications have been discussed. Constructs with neural integration or muscle-tendon units aim to repair muscle atrophy. But it is still difficult to properly bio-print these complex muscles. Although progress can be made by developing new bio-inks or $3 \mathrm{D}$ printers to fabricate highresolution constructs. Using secondary data, this review study shows prospects of why 3D bioprinting can be a good alternate approach to fight cachexia.
\end{abstract}


Keywords: Cancer cachexia, muscle atrophy, tissue regeneration, 3D bioprinting

\section{Introduction}

Weight loss is indicated as a common prognostic factor among all cancer patients. But when it occurs for no apparent reason, even if the patient is consuming adequate nutrition, the patient is left wondering what went wrong. Cancer cachexia is a disease that is a combination of several abnormalities that relate to weight loss (1). Along with weight loss, other abnormalities like loss of muscle and resistance to insulin are seen as well. Almost 2 million people die every year due to cachexia (2,3). $22-25 \%$ of deaths by cancer are reported to be caused by cachexia alone (4). Cachexia is a multiorgan condition that causes skeletal muscle protein-tissue loss or muscle atrophy. The muscle loss can go as high as $75 \%$ and $85 \%$ loss of total body fat (5). As a result, it causes functional impairment as the body's skeletal muscle can regenerate lost tissue upon injury till a certain threshold (6). Furthermore, the patient starts to lose $30 \%$ of body mass and without the use of therapeutics, it can be fatal (7). Due to how cancer cachexia acts, the abnormal metabolism affects fat tissues which can target skeletal muscles, so oncologists are required to estimate the loss of muscle instead of weight (8). A nitrogen flux may occur in the liver from the skeletal muscle. This decreases the supply of branched-chain amino acids in the plasma required to activate the muscle protein synthesis (9). Cancer cachexia negatively impacts a patient's quality of life due to a decrease in mobility, fatigue, and physical activities $(5,10)$.

Molecular mechanism studies regarding cancer cachexia have been undergoing for some time now and it's still not clear exactly what is responsible for its development. Patients face asthenia, anemia, tiredness, and anorexia due to increased exposure to surgical, radiotherapeutic, and chemotherapeutic treatment complications $(8,11)$. In several cases, the timing of the advanced drugs and therapy administration was the reason why there were no beneficial clinical results (12). Patients may experience 3 stages of cancer cachexia according to experts - pre-cachexia, cachexia, and refractory cachexia. So, their treatments are suggested to be initiated quickly so that they can prevent/delay refractory cachexia progression $(10,13)$.

At present, there is no therapy, medicine, or surgery available that is quite effective against cancer cachexia i.e., exempt from side effects. And so, it is very much recommended for people to strive 
to implement healthy lifestyles to prevent this condition. In our aging society, there is a huge medical need for therapies against degenerative muscle disease like cachexia which is rapidly increasing. Furthermore, cachexia still lacks disease-modifying medication (14).

Since its discovery, the success of organ and tissue transplantation for saving patients with incurable diseases has been impeccable. But its biggest drawback is the demand has surpassed the number of donors. And especially regarding muscle tissue donors. But alongside availability, limitations of responding to the immune system and organ rejection also play a role. The concept of tissue engineering with 3D bioprinting works to overcome this very limitation (15). 3D bioprinting has become the most promising method in tissue engineering because of its ability to control geometry. Recent advances in 3D bioprinting technologies enable us to bioengineer various functional skeletal muscle tissue constructs with complex geometry. It is capable of fabricating a wide selection of biomaterials with/without cells in a precise and controlled placement $(16,17)$. A 3D-construct printed structure can also stimulate cellular activities which can enhance the activity of electrically stimulated muscles tissues. The 3D-printed constructs can help to repair or even attempt to replace the loss of muscle that is caused by cachexia (15). Despite experiments being limited to rats or time constraints, 3D bioprinting does pose a good and impressive alternative to solving cachexia and its muscle loss.

\section{Causes and Mediators}

Dysregulation of metabolism, increasing catabolic drives for breaking down fat/protein, and dysregulation of neurohormones are the 3 main factors that drive this disease (Figure-1) (8). 

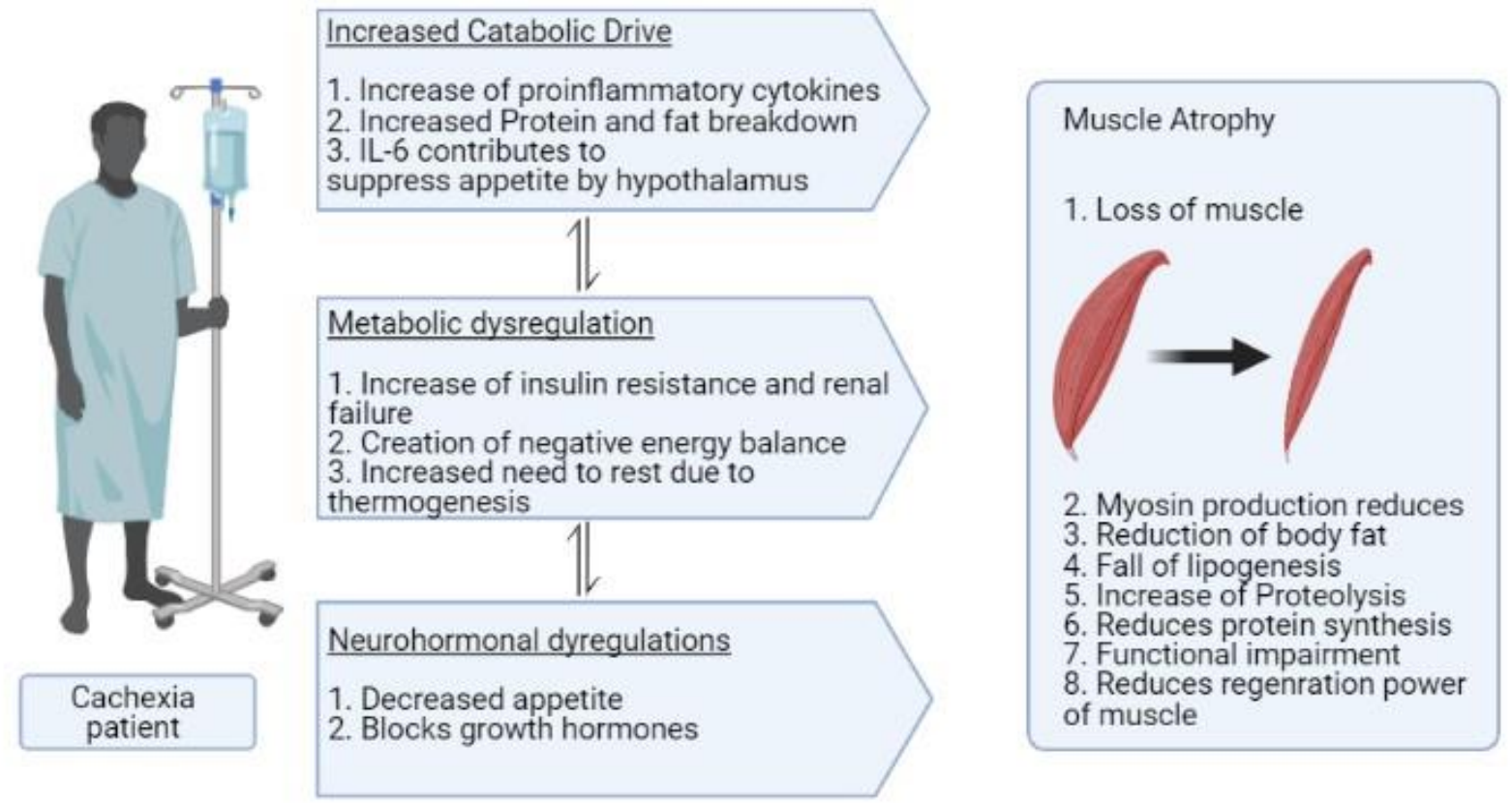

Figure 1. Factors that drive cancer cachexia - Increased catabolic drive, Metabolic dysregulations, and Neurohormonal dysregulations (8).

Muscle loss usually occurs due to protein breakdown. Cancer cachexia makes the myofiber of the cell membrane weak, reduces dystrophin levels, and causes muscle dystrophy (18). People with cancer cachexia mostly have a negative energy balance with an increasing need to rest. Their need to rest increases frequently due to constant thermogenesis, i.e., energy used is increased; energy intake is reduced. So, patients with a good diet and nutrition intake will still lose weight. This in turn makes them unable to do physical activities $(19,20)$.

Blood in our body also plays an active role in cancer cachexia. They are means of transportation for tissue-wasting tumor mediators that include factors contributing to systemic inflammation (Figure-2) (21). Additionally, suppressor cells derived from myeloid (MDSCs) that expand during cancer development were deemed to be a contributor to murine cancer cachexia. This inducted acute phase response (APR) and changed energy metabolic states (22).

The presence of inflammatory cytokines like TNF- $\alpha$, IL- 6 , and IL- $1 \mathrm{~b}$ are mediators that contribute to cancer cachexia $(23,24)$. The activation of TNF plays a role in suppressing appetite which leads to degradation of the proteasomal pathway (9). This is a kind of alteration in mitochondria of skeletal muscle $(9,19)$. 
There is a muscle differentiation and growth regulator which is a negative autocrine, called myostatin. Myostatin signals and activates through pathways associated with ActRII/SMAD2,3 $(23,25)$. Due to tumor burden, activin-A is expressed and secreted in skeletal muscle (26). In recent studies, it was found that GDF11 and MIC-1/GDF15 showed signs as cachexia mediators, where they exerted effects on appetite control, through its recently identified receptor GFRAL. TGF- $\beta$ also mediated cancer-associated muscle weakness $(27,28)$.

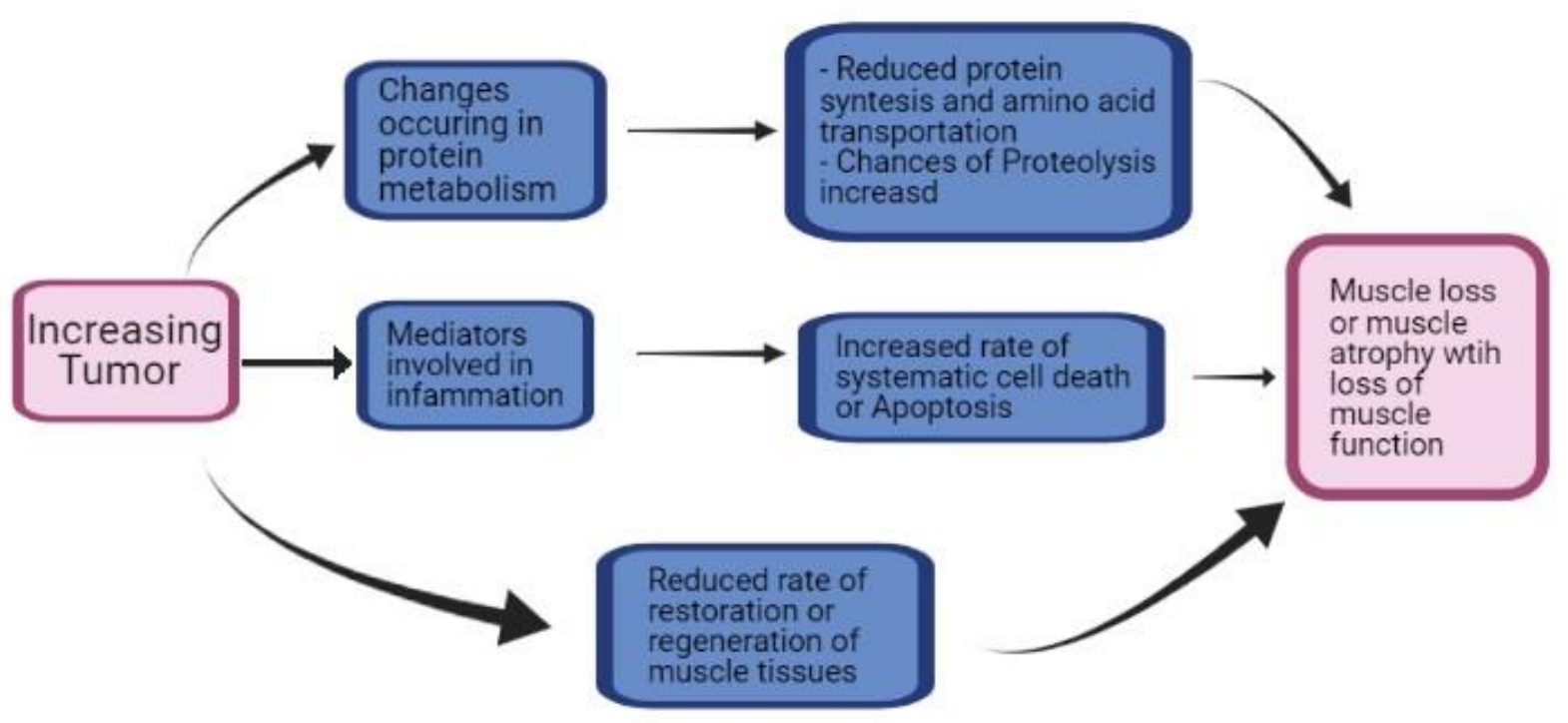

Figure 2. Cancer cachexia causing muscle-wasting, alteration in protein metabolism and reduces regeneration ability of muscles $(19,21)$.

\section{Symptoms and Consequences}

The features of cachexia include loss of weight/muscle to abnormalities in metabolism. Most common symptoms include fatigue and anemia that tire out the patient more than usual due to progressive depletion of the body's energy and protein reserves $(7,29)$. Furthermore, it makes patients more susceptible to develop toxicity related to drugs, ultimately showing poor prognosis (30,31). Along with the loss of skeletal muscle, cancer cachexia also causes cardiac muscle wasting and causes remodeling and dysfunction of cardiac muscle. Thus increasing the chance of cardiac mortality (32,33). Cancer cachexia also causes alterations in the functions of the liver by increasing energy loss in tumor glycolysis production and converting lactate to glucose (Figure-3) (34). 


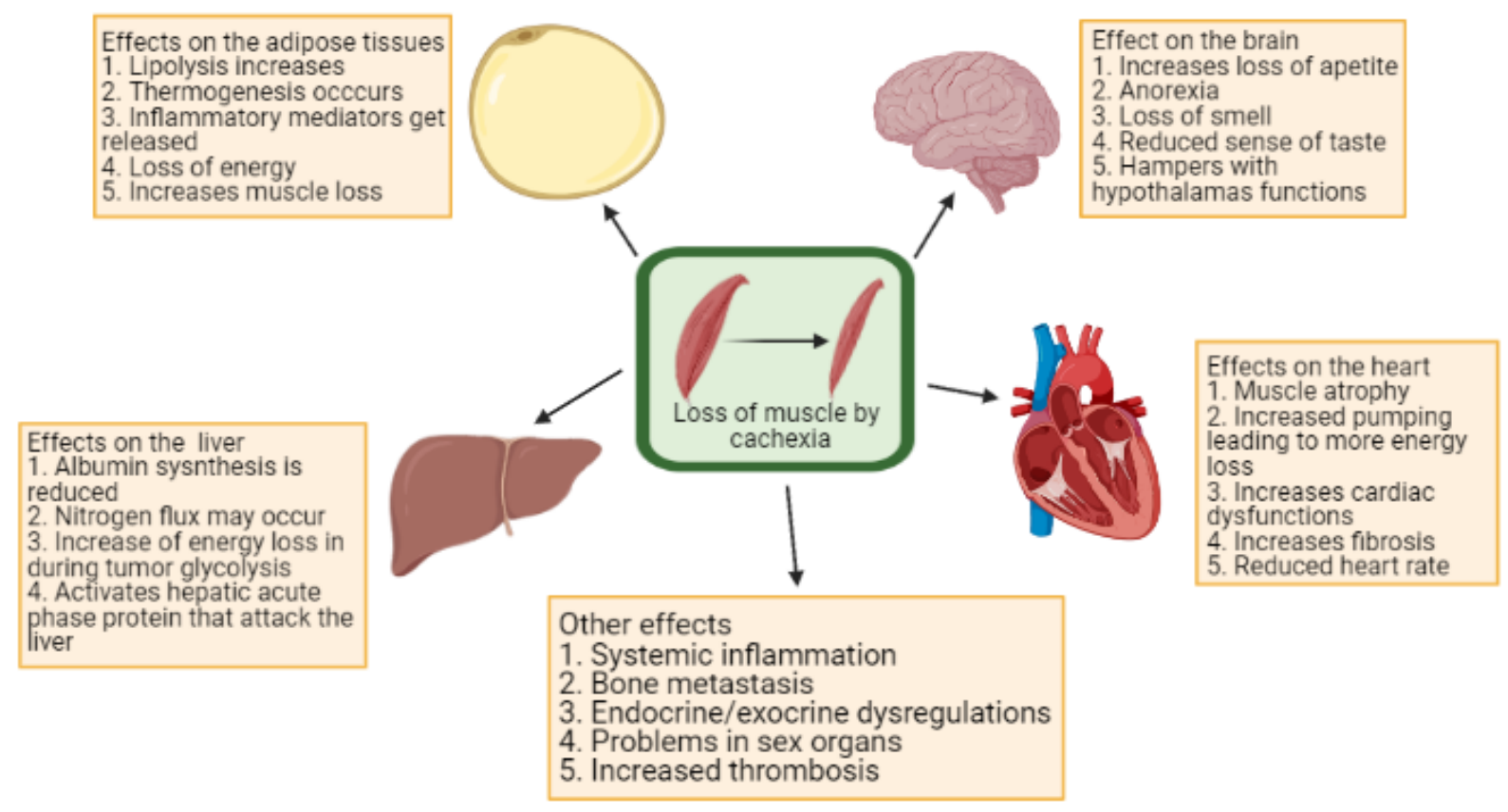

Figure 3. Cancer Cachexia is a multifactorial disease that causes skeletal loss, which contributes to several other problems $(5,6)$.

Due to reduced food intake, the patients face chemosensory distress, hyper-catabolism, and systemic inflammation by abnormal metabolism (13). During chemotherapeutic sessions, patients experience side effects like anorexia, anemia, asthenia, diarrhea, and nausea. They also encounter low intake of food, body pain, depression, and insomnia $(7,30)$. Another problem with cachexia is that it is not reversible by nutritional methods as anabolic response gets altered $(11,13)$.

Cachexia also activates hepatic acute-phase protein which promotes macrophages, produced from IL-1- and IL-6, to infiltrate the liver. This can greatly influence systemic inflammation to escalate in cachexia $(26,35,36)$. Cachexia also promotes loss of bone (Figure-3) $(37,38)$.

\section{Available Remedy and Treatments}

The role of a proper nutritional diet is very important. Without adequate energy and nutrient supply, it isn't possible to increase or stabilize mass and body weight. So, patients are nutritionally monitored early on before they face weight loss. This monitoring consists of providing nutritional and metabolic aid to patients according to their needs $(10,13,39)$. It was seen that fish oil from fatty 
acids possesses the potential to regulate pro-inflammatory cytokines and increase sensitivity to insulin (40). The branched-chain amino acids decrease muscle loss and protein degradation (41). But as it was mentioned before, that this disease cannot be reversed just by providing proper nutrition.

Again, with physical exercises, modulation of skeletal muscle metabolism can improve insulin sensitivity, regulate cellular homeostasis and promote myogenesis (42-44). Exercising is necessary for skeletal muscle metabolism (45). But cachexia patients face difficulty as they have very limited physical capacity. They are subject to fatigue, anemia, cardiac dysfunctions as well, so physical exercise puts quite a toll on them (46).

Many anti-inflammatory agents help to reduce inflammation by cachexia. Corticosteroids are such a drug that helps to reduce fatigue and increase appetite for a short time $(47,48)$. But they are not recommended as extended use can cause muscle wasting side-effects $(49,50)$. In addition to that, even though thalidomide has immunomodulatory and anti-inflammatory properties, it is not recommended due to its severe side effects (51-53). A study showed that by using ActRIIB decoy receptors, the activin type-II-B receptor pathway can be blocked to bring resistance to muscle wasting. But it wasn't successful as it caused patients to suffer from internal bleeding $(54,55)$.

During chemotherapy or chemo-radiotherapy sessions, weight loss is a common observation mostly due to muscle atrophy. The consequences of using cytotoxic and targeted cancer therapies have such direct effects (30).

Autologous muscle transfer is done when muscle atrophy occurs in larger areas, but this can cause trauma or nerve injury hampering motor functions $(56,57)$. Again, grafting of healthy muscle received from a donor site is usually used for restoring the impaired function (58). But such grafting leads to morbidity (59). In addition to that, most grafting procedures can or may fail due to necrosis or infection from the donor itself (60). Allograft and xenograft can activate a severe response from the immune system causing rejection. This occurs due to the presence of antigens in donor tissue (61-63).

Cancer cachexia, being a multidimensional syndrome, makes most unimodal techniques unlikely to succeed. All in all, there are no agents, no effective therapy, surgery nor any medicines that are completely effective against cancer cachexia. 


\section{3D bioprinting}

3D bioprinting technology is a fairly new strategy that can yield positive results regarding regenerative medicine by creating tissue constructs. This strategy mimics the structure of the tissue targeted naturally (64). A 3D scanner is used to check the 3D structure which is retrieved via CT scan, MRI, and ultrasound imaging (15).

There are 3 approaches to bioprinting - biomimicry, autonomous self-assembly, and mini-tissues (65). Biomimicry helps to reproduce specific cellular functional components of tissue by mimicking the cellular microenvironment (66). Autonomous self-assembly uses a guide for creating more complexity. This guide has properties of stem cells and embryonic organs as 3Dbiostructures (67). Mini-tissues help to print smaller functional building blocks on scaffolds and integrate them into a large macrostructure $(68,69)$.

Inkjet-printers are used for non-biological and biological applications (70). With the availability of commercial products and ease of modification, inkjet-bioprinters are used in the bioprinting of tissues and organs (Figure-4). Some major advantages of this are easy accessibility to a bioprinting platform and high processing speed with fairly low cost. But one major drawback lies in the choice of bio-ink material which is quite limited. The material needs to be liquid and viscous enough to be shot out of the nozzle. Cell density is also another issue because too much can clog the nozzle and damaged cells $(15,17)$.

The laser-assisted bioprinting (LAB) works based on modified laser direct writing and laserinduced forward transfer techniques. It can print a wide range of cells while retaining viability (Figure-4) (65). At high resolution, LAB can position the small drops of biomaterial to print highcell densities and hydrogel precursors. This can be done with any desired viscosity $(71,72)$. But the time needed is rather slow and inconvenient for rapid fabrication (73). The use of lasers with UV light can also affect the cells negatively.

Extrusion bioprinters have a broader range of biomaterials. This includes biocompatible copolymers, hydrogels, and cell-spheroids. They are viscous enough to be printed (Figure-4). But it does have limitations like cell death via shear stress and rapid encapsulation of cells $(15,17)$.

Stereolithography (SLA) is a process that is powered by a laser-assisted bioprinting system. This system creates 3D structures by photocuring photopolymerizable liquid polymers which produces realistic microstructures (Figure-4) (74). 


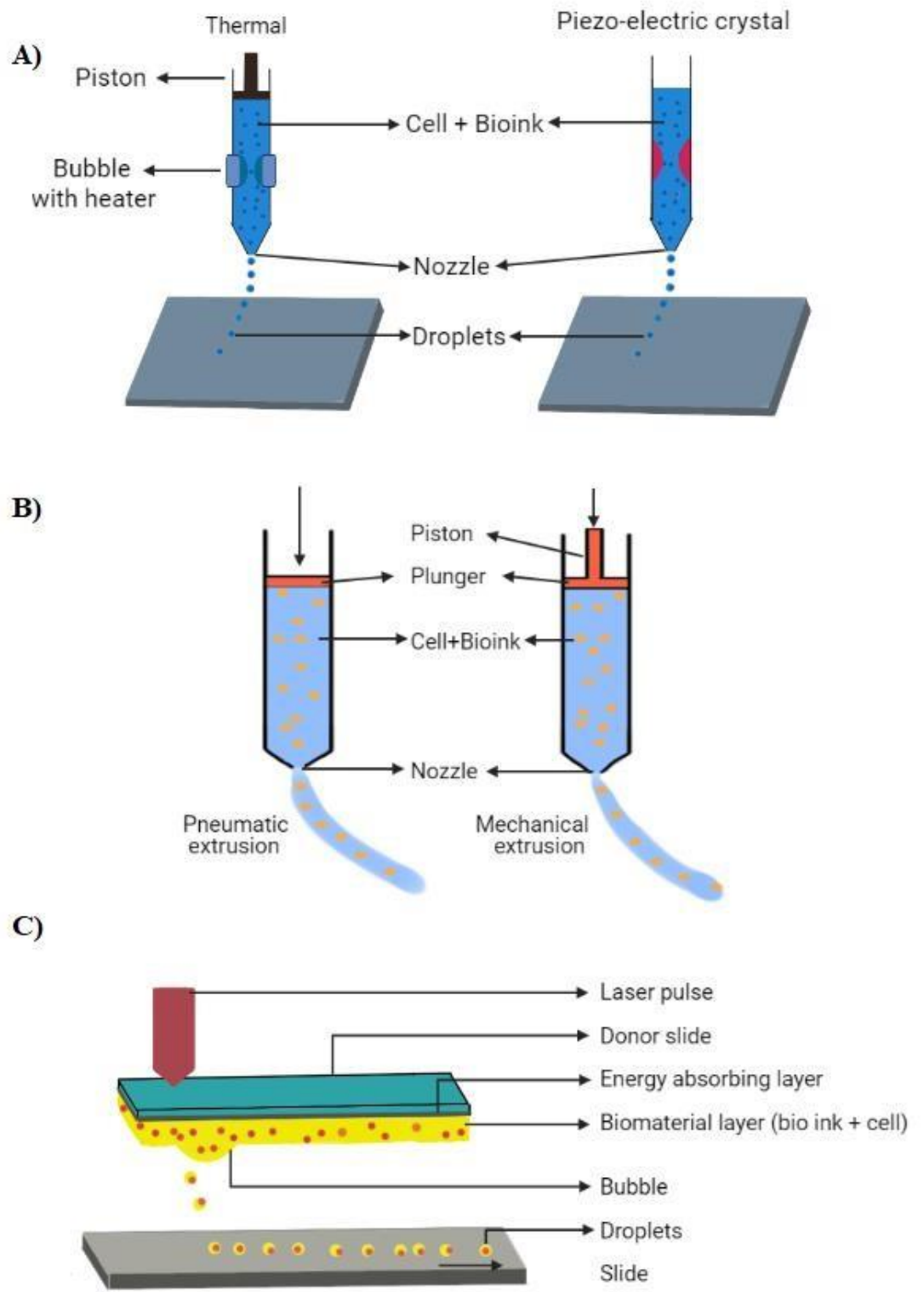

D)

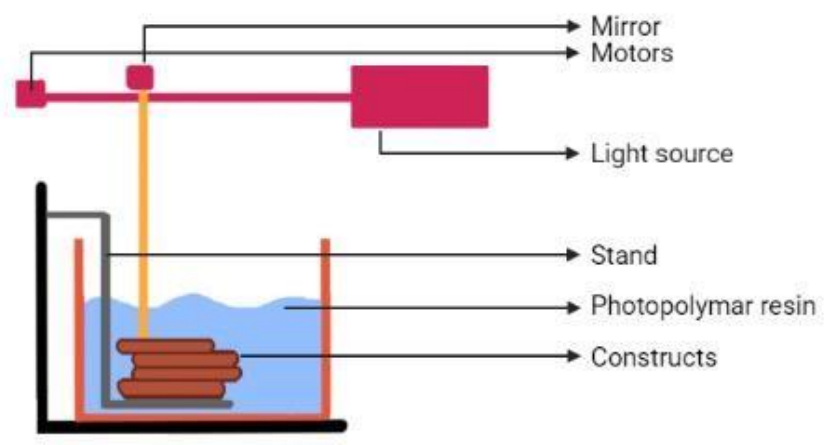


Figure 4 Different methods of 3D bioprinting- A) Inkjet Bioprinting. Cell droplets are printed using either thermal heaters or piezoelectric crystals. B) Extrusion bioprinting. It uses a piston to create air pressure or use mechanical force to get droplets. C) Laser-assisted-bioprinting. The light source helps create a laser that forms bubbles in the bio-material layer and the droplets are got. D) Stereolithography. Here 3D-constructs are created in a layer-by-layer step with the help of photochemical processes $(15,61)$.

\section{Bio-inks}

Bio-inks are living cells and biomaterials that can mimic extracellular matrix environment, cell adhesion, and proliferation after 3D printing. It is a bio-material that is used to construct live tissue. They have usually suspended cells in a liquid solution (75). It consists of only of cells. Most contain an additional carrier material, made of biopolymer gel, that works as a 3D-molecular scaffold. When cells attach to this, they can grow, spread and proliferate. Usually natural or synthetic polymers are selected with good biocompatibility. During the printing process, it is the bio-ink that provides safety to cells. (76).

3D bioprinting uses several kinds of bio-inks to construct cell-laden tissue constructs that have the strength and can keep cells moist while allowing them to print without clogging the nozzle. The materials used are gelatin, Poly (ethylene glycol) alginate, hydrogels, collagen, and hyaluronic acid. Some of the more important features that a bio-ink needs to have are printability, biocompatibility, mechanical property, and ease of spatial arrangement (70).

\section{Printable Biomaterials}

A major obstacle for bioprinting is finding new biomaterials where cells can survive with their potency intact after being printed (77). The biomaterials need to have an enhanced surrounding that helps host tissue formation. Strong and stiff mechanical strength is needed to provide sufficient support, handling, and implantation for cells $(78,79)$. The biomaterials need proper, so that, the internal structures do not break apart (80). The biomaterials should also have maturation, proliferation, biocompatibility, biodegradability, differentiation, and be less immunogenic $(78,81)$. 
The biomaterials used for printing are categorized into synthetic and natural polymers. Synthetic polymers have the mechanical strength needed for printing and processing (82). They help to precisely control molecular weight and functional groups but lack motifs that are cell-responsive. On the other hand, natural polymers are biodegradable and biocompatible. But they are mechanically weak (83).

Some examples of bio-ink can be alginate, gelatin, collagen, fibrin, hyaluronic acid (HA), agarose, chitosan, silk, decellularized extracellular matrix (dECM), poly(ethylene glycol) (PEG), etc. (84).

\section{Available remedies via 3D bioprinting}

\subsection{Muscle Tissue Regeneration by Electrospinning}

Musculoskeletal system injuries are quite common and faulty healing can lead to chronic impairment (85). Several studies and experiments that were based on 3D bioprinting had shown positive results and several advantages in muscle reconstruction (86). Electrospinning is a tool that helps to obtain a fibrous structure. This allows controlling arrangement, structural and biochemical properties with the use of synthetic/natural polymers. Miji Yeo and GeunHyung Kim performed a study where micro-fibrous bundles were uniaxially stretched to obtain a fully aligned 3D structure. The authors developed a process of electrohydrodynamic (EHD) printing with the help of the electrospinning process. They created a 3D-fibrous structure consisting of micro-sized poly $(\varepsilon-$ caprolactone) (PCL) (87). There was great biocompatibility of collagen-coated surfaces as well. All the scaffolds showed high cell viability and proliferation but differentiation was different among scaffolds. To achieve optimal stretching, they stretched the randomly distributed fibers where the 3D-printed cells showed a homogeneous distribution. Thus, proving that this can promote cellular activities. The final structures that were retrieved were from the native muscle structure. Which meant that muscle tissue regeneration was possible (88). Patients suffering from cachexia face skeletal muscle loss. So, using electrospinning, the muscle tissue regeneration for their muscle loss may be possible with further research and experimentations. The high vitality and proliferation with a homogenous distribution that increases cell activities could play a big role when muscle transplants are done to patients. 


\subsection{Creating 3D-functional muscle constructs using Bio-ink and 3D bioprinting}

Despite natural hydrogels (collagen) having properties like good proliferation and differentiation, they are mechanically weak and unstable in the loading process (89). It may not be feasible in the long run. So, in a study conducted by Choi et al, the authors developed a functional muscle construct by using mdECM (extracellular matrix) bio-ink and 3D bioprinting technology. They printed the $\mathrm{C} 2 \mathrm{C} 12$ myoblast encapsulated mdECM bio-ink to create a 3D-muscle construct. They removed the components and preservation of extracellular molecules by decellularization process. The shape and porosity of the construct were manipulated to supply nutrients and oxygen to cells of the tissue construct. This helped enhance cell viability and function (90). The results from the study showed that mdECM bio-ink could print efficiently to produce various shapes of 3D-muscle constructs. This meant that the bio-ink can be used in designing and producing original structures of muscles before implantation. It also had high cell viability ( $>90 \%)$ where cell death was minimal (91). The cell proliferation in MPCs (mdECM bio ink-printed constructs) was seen to increase unlike the CPCs (collagen bio ink-printed constructs). The MPCs had superior myogenic gene expression that causes high cell stimulation and myogenic maturation. There was an indication of the formation of fundamental contractile apparatus that were structurally and functionally mature (92). In addition to that, the 3D-printed muscle constructs were also able to contract in response to electrical stimulation. This study showed that 3D-cell-printing technology and mdECM bio-ink can provide a biomimetic architecture and induce matured myogenic development (93). This technique via $3 \mathrm{D}$ bioprinting shows great promise since the ability to print different $3 \mathrm{D}$-muscle constructs that are similar to the original structures with enhanced vitality is present. It has the potential to develop functional engineered muscle that can fight the likes of cancer cachexia. Cachexia patients lose muscle tissues and cells from their bodies in different proportions. To be able to replace the lost tissues based on the original architectural structure that was lost can be quite useful.

\subsection{Treating skeletal muscle defects using 3D-Bioprinted Muscle Constructs}

Based on their initial success using the ITOP (Integrated tissue-organ printer) system, Kim et al conducted a study to investigate the feasibility of using 3D-bioprinted muscle constructs to treat skeletal muscle defects. In this study, they created skeletal muscle constructs with structural integrity and skeletal muscle tissue organization for functional muscle tissue reconstruction. Using 
ITOP technology, a skeletal muscle construct was bioengineered with the structural organization. The muscle construct had 3 parts - human muscle progenitor cell (hMPC)-laden hydrogel bio-ink, sacrificing acellular gelatin hydrogel bio-ink and a supporting poly( $\varepsilon$-caprolactone) (PCL) polymer. In the live/dead analysis, 3D-bioprinted muscle constructs had multiple myofiber bundles highly organized. It was seen that bio-printed muscle constructs showed high cell viability compared to non-printed muscle constructs. It was also seen that tissue maturation can be accelerated by 3Dprinted organized muscle structure. Again, the microchannel structure allowed the diffusion of nutrients and oxygen that maintained cell viability in the bio-printed constructs. These results showed that the ITOP system can make skeletal muscle constructs with highly viable, differentiated, densely packed myofibers over a broad range of cell densities.

They created a muscle defect by excision of 30-40\% of original TA (Tubagus anterior) muscles in mice (94). This defect caused irreversible functional deficits without any treatment (95). The bioprinted muscle constructs were implanted into the defect region. The created defect resulted in severe muscular atrophy in the non-treated. But it was seen that the bio-printed group maintained their original muscle volume. They also showed a significant increase in their tetanic muscle force and TA muscle weight. They had $82 \%$ restoration of their TA muscle compared to non-printed groups. TA muscle weight in the bio-printed group increased as well. In H\&E and Masson's trichrome staining, the bio-printed muscle group was seen to have superior muscle volume maintenance and myofiber formation with organized architecture. The other groups showed limited development. The bio-printed muscle constructs were more mature and maintained their cellular organization for reconstructing the extensive muscle defect injury. The 3D-ITOP system used in this study allows current limitations of size and spatial organization for the bioengineered skeletal muscle to be overcome. By simultaneous printing of three components, this study was able to create viable skeletal muscle constructs that could mimic cellular function of native skeletal muscle. A microchannel structure was created in bio-printed muscle constructs because large-scale cell-based constructs limit supply of oxygen and nutrients $(96,97)$. This study demonstrated the feasibility of using 3D-bioprinted muscle constructs containing human primary muscle cells. The attributes and results it showed were very positive. To be able to print a high viable muscle tissue construct from a wide range of cell densities is very impressive. The cachexia patients face loss of muscle and muscle weight. But by using 3D bioprinting with PU and PCL there is a chance of $82 \%$ restoration rate of muscle mass and with good maintenance, if done right. But further work is still needed to 
determine if constructs can completely replace native muscle tissues functionally and structurally for humans. It is because the use of rat cells in this method can hinder the translation of drug screening to humans $(65,98,99)$.

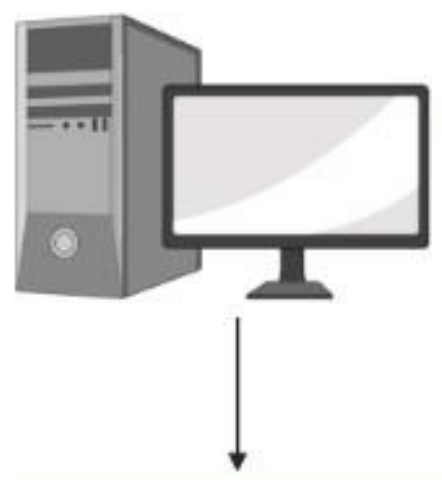

\section{Computer}
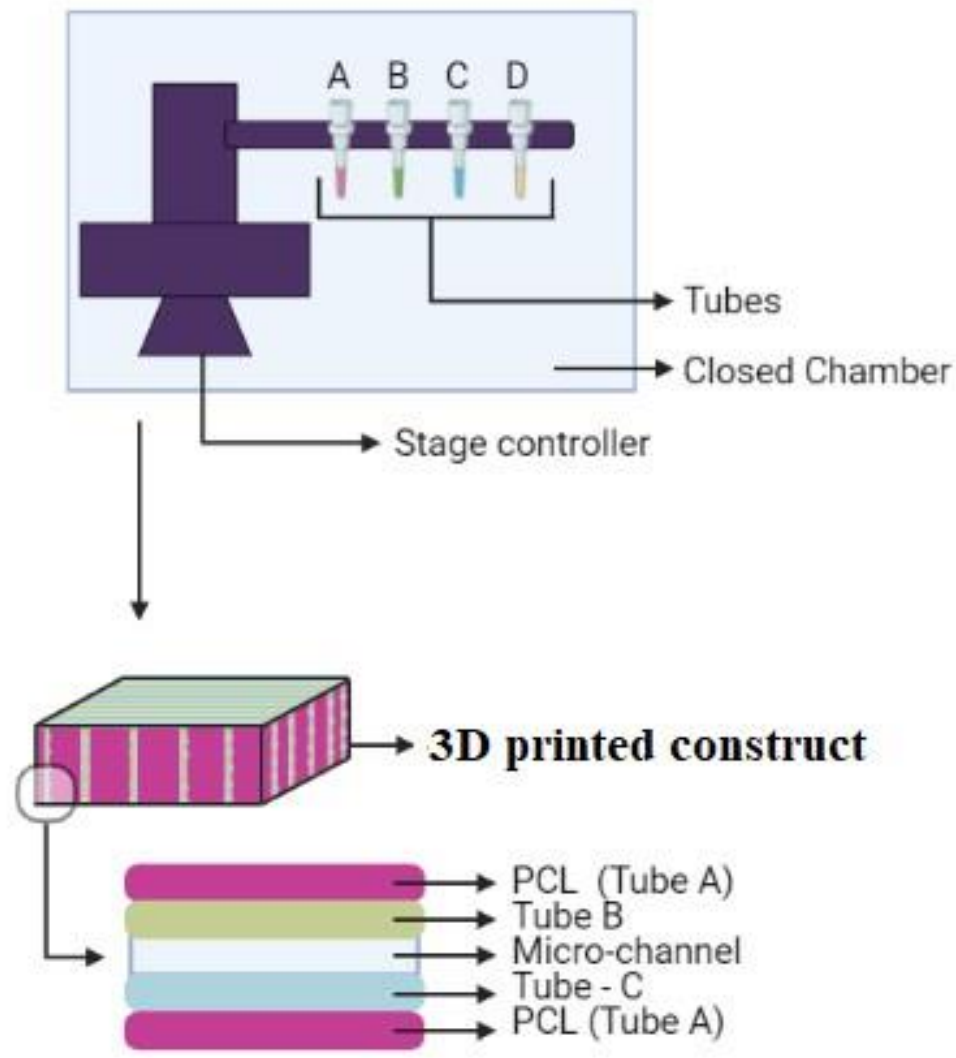

Figure 5. The ITOP system is used to create 3D-constructs using Bio ink and PCL (72). 


\subsection{Restoration of muscle function by neural cell integrated 3D-muscle constructs}

The skeletal muscles that are deprived of nerve supply lose their contractility and face muscle atrophy $(100,101)$. Bioengineered skeletal muscle constructs with cultured muscle cells are denervated and require rapid integration with the host nervous system $(101,102)$. If it fails then muscle atrophy will occur and functional recovery will fail. This is something that most studies did not look into much. And so, Kim et al developed a human skeletal muscle construct that had neural cell integration. It was done by 3D bioprinting human muscle progenitor cells (hMPCs) and human neural stem cells (hNSCs). Neural integration within the construct was able to increase long-term survivability and contribute to maturing bio-engineered skeletal muscle construct. The bio-printed constructs were implanted in a rat model of tibialis-anterior (TA) muscle defect injury to determine the feasibility of using this method. The 3D-bioprinted skeletal muscle constructs had increased the cell survivability and maturation and were implanted in the defective sites for regeneration. The non-treated group showed no sign of recovery and faced severe muscular atrophy. But the 3Dprinted group showed restoration of TA muscle volume and weight. There was a $71.42 \%$ restoration. This showed that for subjects suffering from extensive muscle loss, the introduction of neural cell components in 3D-bioprinted skeletal muscle constructs can enhance the acceleration of muscle restoration and its function. The intervention may take up to 12 weeks in-vivo. So, for constructs to restore the function of muscle in-vivo, rapid innervation is critical with the host nerve. Interestingly, muscle weight in the 3D-bioprinted group was rapidly recovered. Based on muscle force measurement, the 3D-bioprinted group showed full restoration.

Thus, the results indicate that introduction of neural cell components in the bio-printed skeletal muscle constructs could accelerate muscle restoration. In the non-treated group, the surgically excised regions of the TA showed no sign of muscle regeneration, but fibrotic tissue was formed in the defect region, resulting in muscular atrophy. For the success of the bioengineered skeletal muscle constructs to restore the function of injured muscle in-vivo, rapid innervation with the host nerve is critical. In conclusion, neural cell components can support bio-printed skeletal muscle constructs in-vitro, resulting in rapid restoration of muscle function in rat TA muscle defect model (103). Quite similarly like the mentioned previous study showed, this method had the same limitation of being experimented on rats. Further research is needed regarding this because this can work with cachexia. The patients lose their muscle tissue even though they are intaking enough 
nutrition. This problem can be solved if such a 3D bioprinting technique is used. This method showed that there is long survivability and maturation of muscle tissue. $71.42 \%$ restoration rate and that too with rapidness is something to incorporate in clinical trials for cachexia patients.

\subsection{Engineering integrated muscle-tendon unit via 3D-bio-fabricating complex structures}

Usually, tissue-engineered constructs with a porous structure can be manually seeded with cells $(104,105)$. This method has drawbacks like having difficulty homogeneously seed a scaffold, being unable to distribute multiple cell types, and poor control with scaffold micro-architecture. 3D bioprinting has the potential to solve these limitations $(70,106)$. For that Tyler et al, made 3D-biofabrication of complex structures. They used multiple synthetic biomaterials and multiple cell types to engineer an integrated muscle-tendon-unit (MTU). Two synthetic polymeric materials as the scaffolding component and two cell-laden hydrogel-based bio-inks as the cellular component were used for the MTU construct. The scaffolding component served as a biomechanical and functional structure, while the cellular component was the biological source of tissue development. The MTU was constructed with thermoplastic-polyurethane (PU) and C2C12 myoblasts for the muscle side and poly(e-caprolactone) (PCL) and NIH/3T3 fibroblasts for the tendon side. These two were chosen as PU and PCL can mimic muscle elasticity and tendon's stiffness respectively. The PU side was more elastic than the PCL side although the tensile strength didn't differ. To re-create the MTU, a construct with three distinct regions was made - muscle side with printed PU, tendon side with printed PCL, and MTJ (muscle-tendon junction) region with overlapped PU-PCL. It was seen that the cells survived the printing process and started to develop into linearized tissue. It mimicked the biological architecture of natural muscle and tendon. In addition to that, it was observed that dense collagen deposition had formed by the NIH/3T3 cells. This marked the initial development of the tendon. This led to high cell viability with C2C12 (92.7 $\pm 2.5 \%)$ and NIH/3T3 $(89.1 \pm 3.3 \%)$ (107). It was seen that cells retained their original position and organized themselves into a consistent pattern. They were able to show that there was an increase in transcription of the focal adhesion markers. The advantage of having constructs made from synthetic polymers and cellladen bio-inks offers the ability to expose them to biomechanical stimulation. So, they were able to print cells with good viability. These cells were aligned into highly aligned morphology of muscle and tendon, and have increased MTJ-associated gene expression. 
One limitation in this study was noticed which was the time needed for constructs to be cultured. A relatively long time frame was needed to generate a complete integrated muscle-tendon tissue unit. It is because the MTJ development requires collagen deposition before focal adhesions can form between the muscle and tendon (108). This study showed that it is possible to print muscle cells using 3D-bioprinting. The end products that would be implanted in cachexia patients would be structurally and biomechanically functional and have normal biological tissue development. The 3D construct after being printed becomes a linearized tissue that can imitate a natural muscle tissue. This can pave the way to restore the loss of muscle caused by cachexia. The time limitation seems only like a small drawback for a better life ahead.

\section{Use of 3D bioprinting other fields and their limitations}

3D bioprinting has been experimented with and researched about for a while now. It is being used to treat cardiovascular diseases (CVD) as well. Experiments by printing 3D constructs and implementing them on mice and several other trials are being conducted. The use of tissue implants via grafting has been done earlier but issues with tissue rejection and lack of donors cause problems (109-111). CVD leads to cell structures of the heart deteriorating and this requires replacement. 3D bioprinting technology is being used to make these replacements. The construction of cardiac patches using biomaterials and bio-inks has been done to restore functions of damaged myocardium. Atmanli et al, constructed 3D-functional cardiac patches which were able to maintain the structure of myocardial tissue (112). In another study led by Ong et al, they were able to make 3D-biomaterial cardiac patches that were spontaneously beating (113). Xu et al., constructed functional cardiac pseudo-tissues with structural support using ink-jet printing. When it was subjected to mild electrical stimuli, it showed contractile behavior (114). However, inkjet printers are only compatible with low viscosity. This results in constructs made from ink-jet printers having weaker mechanical properties $(70,115,116)$. In addition to that, due to a discretized flow, restriction to thin structures is also seen along with excessive thermal stress and the risk of cell lysis (115). Such situations can have negative impacts on the viability and functionality of cells. Using the LAB system allows high cell density, cell viability, and the selection of a single cell for transfer $(110,117)$. LAB's resolution depends on many parameters and it also costs a lot, so this system is not commercially available (110,118). The SLA technique in bioprinting of 3D-cardiac patches and heart valves has demonstrated a lot of potential such as reduced time for printing, greater accuracy 
of fabrication, and higher cell viability (115). But they also have adverse effects due to the use of lasers and the optics required are expensive (74). The construction of tissue with a high oxygen consumption rate is still difficult. When bioprinting vascularized thick tissues, printing capillaries at the submicron scale is difficult $(17,119)$.

The study of 3D-bioprinted vasculature was conducted in immunodeficient mice to verify effectiveness. Studies have been able to generate endothelium by colonizing endothelial cells but the native structure is so complicated that it isn't easy to replicate them properly $(120,121)$. To obtain rapid gelation for 3D-bioprinting, it was seen that a solution of higher than $15 \mathrm{wt} \%$ is best to use for GelMA/C after numerous trials. Although it became difficult to handle when the concentration of the bio-ink solution went over 30wt\%. It was mostly due to high viscosity. But the major advantage is that the 3D-bioprinted vasculature replicates biomimetic vessel structures that contain smooth muscle and endothelium. So, researchers are now considering 3D bioprinting of tissue constructs with some optimization that is still required to improve the methods (122).

Similarly, for skeletal muscle regeneration, 3D bioprinting has come a long way. Several studies have been conducted as well over the years. For example, by the use of electrospinning, muscle tissue can be regenerated with future research and experimentations. The high vitality and proliferation of constructs with a homogenous distribution that increases cell activities could play a big role when muscle transplants are done to patients. Different shapes of 3D-muscle constructs physically printed out according to their native structure have the potential to reduce muscle atrophy. Patients with cachexia encounter loss of muscle tissues even while intaking nutrition daily. Since cachexia patients lose muscle tissue in an abhorrent way, being able to make replicants of lost tissues based on the original architectural structure can give people hope and the will to keep fighting.

3D bioprinting techniques conducted on mice specimens have shown positive results. It is impressive to print from a wide range of cell densities. These 3D bioprinters, which will be implanted in the host subject are assumed to get a normal biological tissue development and mimic natural muscle tissue. They can work and function like the original muscle that was lost. But since they were conducted on mice it is still not sure how it will work for human grafting and implanting. Studies have already shown that it is very much possible to use a 3D-bioprinted muscle construct and have muscle restoration and maturation. 


\section{Conclusion}

Several technologies and methods have been used to generate 3D-muscle constructs, but none of these methods has succeeded to mimic the native morphology of muscle tissues $(123,124)$. But among these, 3D bioprinting technology has emerged as a powerful tool to build bioengineered skeletal muscle constructs. It is because these methods can generate structurally complex cell-based constructs by precise positioning of multiple cell types, bioactive factors, and biomaterials within a single architecture to mimic native tissues $(65,93,125,126)$. 3D bioprinting has been able to construct much more accurately dense constructs with rapid maturation $(70,125,127)$. But further research and developments are required in 3D bioprinting for skeletal muscle for humans. In the case of skeletal muscle tissue, there are many cell sources available but most of them have a limited capacity to be expanded in-vitro. So even with the progression made so far, 3D bioprinting still faces tough challenges. Problems like lacking a proper biocompatible bio-ink, with supportive mechanical properties for 3D-cell culture, can cause cells to have reduced accuracy and structural organization $(93,125)$. But it does offer hope and a chance for survival. Because in comparison to conventional models, 3D bioprinting can offer more freedom for the development of engineering skeletal muscle tissues (128). Available methods via 3D bioprinting may have their drawbacks like time constraints, tests limited to mice, etc. But these are just some minor setbacks that can be outdone in the future with more research and experiments.

As methods for 3D bioprinting technology continue to become more widespread, it can be anticipated that applications regarding 3D bioprinting will improve in the upcoming years given that cells and tissues can be constructed to create 3D-bioprinted muscle constructs and tendon units. These alone are enough to take these methods into an application for cachexia. Developing new bio-inks and printers that are capable of projecting high-resolution constructs can help improve the method. More in-depth study regarding muscle tissues and how they function can also help in future experiments. In the end, it is very plausible that 3D bioprinting will ultimately be able to fend off the muscle loss problem caused by cachexia.

\section{Conflict of Interest}

The authors declare no conflict of interest regarding the publication of the manuscript. 


\section{Funding Statement}

The authors received no specific funding from any external sources.

\section{References}

1. Mattox TW. Cancer Cachexia: Cause, Diagnosis, and Treatment. Nutr Clin Pract. 2017;32(5):599-606.

2. Muscaritoli M, Bossola M, Aversa Z, Bellantone R, Rossi Fanelli F. Prevention and treatment of cancer cachexia: New insights into an old problem. Eur J Cancer. 2006;42(1):31-41.

3. Inui A. Cancer Anorexia-Cachexia Syndrome: Current Issues in Research and Management. CA Cancer J Clin. 2002;52(2):72-91.

4. Barreto R, Mandili G, Witzmann FA, Novelli F, Zimmers TA, Bonetto A. Cancer and chemotherapy contribute to muscle loss by activating common signaling pathways. Front Physiol. 2016;7(OCT):1-13.

5. Tisdale MJ. Mechanisms of cancer cachexia. Physiol Rev. 2009;89(2):381-410.

6. Tedesco FS, Dellavalle A, Diaz-manera J, Messina G, Cossu G. Repairing skeletal muscle: regenerative potential ... [J Clin Invest. 2010] - PubMed result. 2010;120(1). Available from:

http://www.ncbi.nlm.nih.gov/pubmed/20051632\%5Cnpapers3://publication/uuid/906207 AB-C2A8-490C-9F9D-8C97F7ED6944

7. Penna F, Ballarò R, Beltrà M, De Lucia S, Castillo LG, Costelli $\mathrm{P}$. The skeletal muscle as an active player against cancer cachexia. Front Physiol. 2019;10(FEB).

8. Bruggeman AR, Kamal AH, LeBlanc TW, Ma JD, Baracos VE, Roeland EJ. Cancer cachexia: Beyond weight loss. J Oncol Pract. 2016;12(11):1163-71.

9. Burckart K, Beca S, Urban RJ, Sheffield-Moore M. Pathogenesis of muscle wasting in cancer cachexia: Targeted anabolic and anticatabolic therapies. Curr Opin Clin Nutr Metab 
Care. 2010;13(4):410-6.

10. Muscaritoli M, Molfino A, Gioia G, Laviano A, Fanelli FR. The "parallel pathway": A novel nutritional and metabolic approach to cancer patients. Intern Emerg Med. 2011;6(2):105-12.

11. Reynolds J V., Donohoe CL, Ryan AM. Cancer cachexia: Mechanisms and clinical implications. Gastroenterol Res Pract. 2011;2011.

12. Prado CM, Sawyer MB, Ghosh S, Lieffers JR, Esfandiari N, Antoun S, et al. Central tenet of cancer cachexia therapy: Do patients with advanced cancer have exploitable anabolic potential? Am J Clin Nutr. 2013;98(4):1012-9.

13. Fearon K, Strasser F, Anker SD, Bosaeus I, Bruera E, Fainsinger RL, et al. Definition and classification of cancer cachexia: An international consensus. Lancet Oncol [Internet]. 2011;12(5):489-95. Available from: http://dx.doi.org/10.1016/S1470-2045(10)70218-7

14. Tabebordbar M, Wang ET, Wagers AJ. Skeletal muscle degenerative diseases and strategies for therapeutic muscle repair. Annu Rev Pathol Mech Dis. 2013;8:441-75.

15. Hong N, Yang GH, Lee JH, Kim GH. 3D bioprinting and its in vivo applications. J Biomed Mater Res - Part B Appl Biomater. 2018;106(1):444-59.

16. Cui X, Boland T, D.D’Lima D, K. Lotz M. Thermal Inkjet Printing in Tissue Engineering and Regenerative Medicine. Recent Pat Drug Deliv Formul. 2012;6(2):149-55.

17. Ozbolat IT, Yu Y. Bioprinting Toward Organ Fabrication : Challenges and Future Trends Bioprinting Toward Organ Fabrication : Challenges and Future Trends. IEEE Trans Biomed Eng. 2015;60(November):691-9.

18. Inaba S, Hinohara A, Tachibana M, Tsujikawa K, Fukada S. Muscle regeneration is disrupted by cancer cachexia without loss of muscle stem cell potential. PLoS One. 2018;13(10):1-15.

19. Penna F, Ballarò R, Beltrá M, De Lucia S, Costelli P. Modulating metabolism to improve cancer-induced muscle wasting. Oxid Med Cell Longev. 2018;2018.

20. Argilés JM, Busquets S, Stemmler B, López-Soriano FJ. Cancer cachexia: Understanding 
the molecular basis. Nat Rev Cancer [Internet]. 2014;14(11):754-62. Available from: http://dx.doi.org/10.1038/nrc3829

21. Martignoni ME, Kunze P, Hildebrandt W, Künzli B, Berberat P, Giese T, et al. Role of mononuclear cells and inflammatory cytokines in pancreatic cancer-related cachexia. Clin Cancer Res. 2005;11(16):5802-8.

22. Cuenca AG, Cuenca AL, Winfield RD, Joiner DN, Gentile L, Delano MJ, et al. Novel Role for Tumor-Induced Expansion of Myeloid-Derived Cells in Cancer Cachexia. J Immunol. 2014;192(12):6111-9.

23. Fearon $\mathrm{KCH}$, Glass DJ, Guttridge DC. Cancer cachexia: Mediators, signaling, and metabolic pathways. Cell Metab. 2012;16(2):153-66.

24. Petruzzelli M, Wagner EF. Mechanisms of metabolic dysfunction in cancer-associated cachexia. Genes Dev. 2016;30(5):489-501.

25. Cohen S, Nathan JA, Goldberg AL. Muscle wasting in disease: Molecular mechanisms and promising therapies. Nat Rev Drug Discov [Internet]. 2014;14(1):58-74. Available from: http://dx.doi.org/10.1038/nrd4467

26. Schmidt SF, Rohm M, Herzig S, Berriel Diaz M. Cancer Cachexia: More Than Skeletal Muscle Wasting. Trends in Cancer [Internet]. 2018;4(12):849-60. Available from: https://doi.org/10.1016/j.trecan.2018.10.001

27. Jones JE, Cadena SM, Gong C, Wang X, Chen Z, Wang SX, et al. Supraphysiologic Administration of GDF11 Induces Cachexia in Part by Upregulating GDF15. Cell Rep [Internet]. 2018;22(6):1522-30. Available from: https://doi.org/10.1016/j.celrep.2018.01.044

28. Yang L, Chang CC, Sun Z, Madsen D, Zhu H, Padkjær SB, et al. GFRAL is the receptor for GDF15 and is required for the anti-obesity effects of the ligand. Nat Med. 2017;23(10):1158-66.

29. Baracos VE, Martin L, Korc M, Guttridge DC, Fearon KCH. Cancer-associated cachexia. Nat Rev Dis Prim [Internet]. 2018;4:1-18. Available from: http://dx.doi.org/10.1038/nrdp.2017.105 
30. Baracos VE, Mazurak VC, Bhullar AS. Cancer cachexia is defined by an ongoing loss of skeletal muscle mass. Ann Palliat Med. 2019;8(1):3-12.

31. Antoun S, Baracos VE, Birdsell L, Escudier B, Sawyer MB. Low body mass index and sarcopenia associated with dose-limiting toxicity of sorafenib in patients with renal cell carcinoma. Ann Oncol. 2010;21(8):1594-8.

32. Murphy KT. The pathogenesis and treatment of cardiac atrophy in cancer cachexia. Am J Physiol - Hear Circ Physiol. 2016;310(4):H466-77.

33. Von Haehling S, Ebner N, Dos Santos MR, Springer J, Anker SD. Muscle wasting and cachexia in heart failure: Mechanisms and therapies. Nat Rev Cardiol [Internet]. 2017;14(6):323-41. Available from: http://dx.doi.org/10.1038/nrcardio.2017.51

34. Friesen DE, Baracos VE, Tuszynski JA. Modeling the energetic cost of cancer as a result of altered energy metabolism: Implications for cachexia. Theor Biol Med Model [Internet]. 2015;12(1):1-18. Available from: http://dx.doi.org/10.1186/s12976-015-0015-0

35. Fearon KCH, Barber MD, Falconer JS, McMillan DC, Ross JA, Preston T. Pancreatic cancer as a model: Inflammatory mediators, acute-phase response, and cancer cachexia. World J Surg. 1999;23(6):584-8.

36. Preston T, Slater C, McMillan DC, Falconer JS, Shenkin A, Fearon KCH. Fibrinogen synthesis is elevated in fasting cancer patients with an acute phase response. $\mathrm{J}$ Nutr. 1998;128(8):1355-60.

37. Bonetto A, Kays JK, Parker VA, Matthews RR, Barreto R, Puppa MJ, et al. Differential bone loss in mouse models of colon cancer cachexia. Front Physiol. 2017;7(JAN).

38. Choi E, Carruthers K, Zhang L, Thomas N, Battaglino RA, Morse LR, et al. Concurrent muscle and bone deterioration in a murine model of cancer cachexia. Physiol Rep. 2013;1(6):1-9.

39. Martin L, Senesse P, Gioulbasanis I, Antoun S, Bozzetti F, Deans C, et al. Diagnostic criteria for the classification of cancer-associated weight loss. J Clin Oncol. 2015;33(1):909. 
40. Dewey A, Baughan C, Dean T, Higgins B, Johnson I. Eicosapentaenoic acid (EPA, an omega-3 fatty acid from fish oils) for the treatment of cancer cachexia. Cochrane Database Syst Rev. 2007;(1).

41. Eley HL, Russell ST, Tisdale MJ. Effect of branched-chain amino acids on muscle atrophy in cancer cachexia. Biochem J. 2007;407(1):113-20.

42. Gould DW, Lahart I, Carmichael AR, Koutedakis Y, Metsios GS. Cancer cachexia prevention via physical exercise: Molecular mechanisms. J Cachexia Sarcopenia Muscle. 2013;4(2):111-24.

43. Snijders T, Nederveen JP, McKay BR, Joanisse S, Verdijk LB, van Loon LJC, et al. Satellite cells in human skeletal muscle plasticity. Front Physiol. 2015;6(OCT):1-21.

44. Aversa Z, Costelli P, Muscaritoli M. Cancer-induced muscle wasting: Latest findings in prevention and treatment. Ther Adv Med Oncol. 2017;9(5):369-82.

45. Penna F, Pin F, Ballarò R, Baccino FM, Costelli P. Novel investigational drugs mimicking exercise for the treatment of cachexia. Expert Opin Investig Drugs. 2016;25(1):63-72.

46. Argilés JM, Busquets S, López-Soriano FJ, Costelli P, Penna F. Are there any benefits of exercise training in cancer cachexia? J Cachexia Sarcopenia Muscle. 2012;3(2):73-6.

47. Yennurajalingam S, Frisbee-Hume S, Palmer JL, Delgado-Guay MO, Bull J, Phan AT, et al. Reduction of cancer-related fatigue with dexamethasone: A double-blind, randomized, placebo-controlled trial in patients with advanced cancer. J Clin Oncol. 2013;31(25):307682.

48. Paulsen $\varnothing$, Klepstad P, Rosland JH, Aass N, Albert E, Fayers P, et al. Efficacy of methylprednisolone on pain, fatigue, and appetite loss in patients with advanced cancer using opioids: A randomized, placebo-controlled, double-blind trial. J Clin Oncol. 2014;32(29):3221-8.

49. Fardet L, Flahault A, Kettaneh A, Tiev KP, Généreau T, Tolédano C, et al. Corticosteroidinduced clinical adverse events: Frequency, risk factors and patient's opinion. Br J Dermatol. 2007;157(1):142-8. 
50. Hasselgren PO, Alamdari N, Aversa Z, Gonnella P, Smith IJ, Tizio S. Corticosteroids and muscle wasting: Role of transcription factors, nuclear cofactors, and hyperacetylation. Curr Opin Clin Nutr Metab Care. 2010;13(4):423-8.

51. Reid J, Mills M, Cantwell M, Cardwell CR, Murray LJ, Donnelly M. Thalidomide for managing cancer cachexia. Cochrane Database Syst Rev. 2012;2012(4).

52. Davis M, Lasheen W, Walsh D, Mahmoud F, Bicanovsky L, Lagman R. A phase II dose titration study of thalidomide for cancer-associated anorexia. J Pain Symptom Manage [Internet]. 2012;43(1):78-86. Available from: http://dx.doi.org/10.1016/j.jpainsymman.2011.03.007

53. Yennurajalingam S, Willey JS, Palmer JL, Allo J, Fabbro E Del, Cohen EN, et al. The role of thalidomide and placebo for the treatment of cancer-related anorexia-cachexia symptoms: Results of a double-blind placebo-controlled randomized study. J Palliat Med. 2012;15(10):1059-64.

54. Zhou X, Wang JL, Lu J, Song Y, Kwak KS, Jiao Q, et al. Reversal of cancer cachexia and muscle wasting by ActRIIB antagonism leads to prolonged survival. Cell [Internet]. 2010;142(4):531-43. Available from: http://dx.doi.org/10.1016/j.cell.2010.07.011

55. Benny Klimek ME, Aydogdu T, Link MJ, Pons M, Koniaris LG, Zimmers TA. Acute inhibition of myostatin-family proteins preserves skeletal muscle in mouse models of cancer cachexia. Biochem Biophys Res Commun [Internet]. 2010;391(3):1548-54. Available from: http://dx.doi.org/10.1016/j.bbrc.2009.12.123

56. Stevanovic M V., Cuéllar VG, Ghiassi A, Sharpe F. Single-stage reconstruction of elbow flexion associated with massive soft-tissue defect using the latissimus dorsi muscle bipolar rotational transfer. Plast Reconstr Surg - Glob Open. 2016;4(9):1-9.

57. Makarewich CA, Hutchinson DT. Tendon Transfers for Combined Peripheral Nerve Injuries. Hand Clin [Internet]. 2016;32(3):377-87. Available from: http://dx.doi.org/10.1016/j.hcl.2016.03.008

58. Eckardt A, Fokas K. Microsurgical reconstruction in the head and neck region: An 18-year experience with 500 consecutive cases. J Cranio-Maxillofacial Surg. 2003;31(4):197-201. 
59. Lin CH, Lin Y Te, Yeh JT, Chen CT. Free functioning muscle transfer for lower extremity posttraumatic composite structure and functional defect. Plast Reconstr Surg. 2007;119(7):2118-26.

60. Bianchi B, Copelli C, Ferrari S, Ferri A, Sesenna E. Free flaps: Outcomes and complications in head and neck reconstructions. J Cranio-Maxillofacial Surg [Internet]. 2009;37(8):43842. Available from: http://dx.doi.org/10.1016/j.jcms.2009.05.003

61. Liu J, Saul D, Böker KO, Ernst J, Lehman W, Schilling AF. Current Methods for Skeletal Muscle Tissue Repair and Regeneration. Biomed Res Int. 2018;2018.

62. Badylak SF, Gilbert TW. Immune response to biologic scaffold materials. Semin Immunol. 2008;20(2):109-16.

63. Lotze MT, Deisseroth A, Rubartelli A. Damage associated molecular pattern molecules. Clin Immunol. 2007;124(1):1-4.

64. Bertassoni LE, Cardoso JC, Manoharan V, Cristino AL, Bhise NS, Araujo WA, et al. Directwrite bioprinting of cell-laden methacrylated gelatin hydrogels. Biofabrication. 2014;6(2).

65. Kim JH, Seol YJ, Ko IK, Kang HW, Lee YK, Yoo JJ, et al. 3D Bioprinted Human Skeletal Muscle Constructs for Muscle Function Restoration. Sci Rep [Internet]. 2018;8(1):1-15. Available from: http://dx.doi.org/10.1038/s41598-018-29968-5

66. Vigodarzere GC, Mantero S. Skeletal muscle tissue engineering: Strategies for volume tric constructs. Front Physiol. 2014;5(September):1-14.

67. Juhas M, Ye J, Bursac N. Design, evaluation, and application of engineered skeletal muscle. Methods [Internet]. 2016;99:81-90. Available from: http://dx.doi.org/10.1016/j.ymeth.2015.10.002

68. Ostrovidov S, Hosseini V, Ahadian S, Fujie T, Parthiban SP, Ramalingam M, et al. Skeletal muscle tissue engineering: Methods to form skeletal myotubes and their applications. Tissue Eng - Part B Rev. 2014;20(5):403-36.

69. Bian W, Liau B, Badie N, Bursac N. Mesoscopic hydrogel molding to control the 3d geometry of bioartificial muscle tissues. Nat Protoc [Internet]. 2009;4(10):1522-34. 
Available from: http://dx.doi.org/10.1038/nprot.2009.155

70. Murphy S V., Atala A. 3D bioprinting of tissues and organs. Nat Biotechnol [Internet]. 2014;32(8):773-85. Available from: http://dx.doi.org/10.1038/nbt.2958

71. Guillotin B, Souquet A, Catros S, Duocastella M, Pippenger B, Bellance S, et al. Laser assisted bioprinting of engineered tissue with high cell density and microscale organization. Biomaterials [Internet]. 2010;31(28):7250-6. Available from: http://dx.doi.org/10.1016/j.biomaterials.2010.05.055

72. Koch L, Deiwick A, Schlie S, Michael S, Gruene M, Coger V, et al. Skin tissue generation by laser cell printing. Biotechnol Bioeng. 2012;109(7):1855-63.

73. Wang M, He J, Liu Y, Li M, Li D, Jin Z. The trend towards. Int J Bioprinting. 2015;1(1):1526.

74. Rider P, Kačarević ŽP, Alkildani S, Retnasingh S, Barbeck M. Bioprinting of tissue engineering scaffolds. J Tissue Eng. 2018;9.

75. Stanton MM, Samitier J, Sánchez S. Bioprinting of 3D hydrogels. Lab Chip [Internet]. 2015;15(15):3111-5. Available from: http://dx.doi.org/10.1039/C5LC90069G

76. Pires R. What exactly is Bioink? - Simply Explained. All3DP [Internet]. 2018; Available from: https://all3dp.com/2/for-ricardo-what-is-bioink-simply-explained/

77. Thiele J, Ma Y, Bruekers SMC, Ma S, Huck WTS. 25th anniversary article: Designer hydrogels for cell cultures: A materials selection guide. Adv Mater. 2014;26(1):125-48.

78. Arealis G, Nikolaou VS. Bone printing: New frontiers in the treatment of bone defects. Injury [Internet]. 2015;46:S20-2. Available from: http://dx.doi.org/10.1016/S00201383(15)30050-4

79. Huang Y, Zhang XF, Gao G, Yonezawa T, Cui X. 3D bioprinting and the current applications in tissue engineering. Biotechnol J. 2017;12(8).

80. Billiet T, Vandenhaute M, Schelfhout J, Van Vlierberghe S, Dubruel P. A review of trends and limitations in hydrogel-rapid prototyping for tissue engineering. Biomaterials [Internet]. 2012;33(26):6020-41. Available from: 
http://dx.doi.org/10.1016/j.biomaterials.2012.04.050

81. Murphy S V., Skardal A, Atala A. Evaluation of hydrogels for bio-printing applications. J Biomed Mater Res - Part A. 2013;101 A(1):272-84.

82. Peppas NA, Hilt JZ, Khademhosseini A, Langer R. Hydrogels in biology and medicine: From molecular principles to bionanotechnology. Adv Mater. 2006;18(11):1345-60.

83. Dimas LS, Buehler MJ. Modeling and additive manufacturing of bio-inspired composites with tunable fracture mechanical properties. Soft Matter. 2014;10(25):4436-42.

84. Gungor-Ozkerim PS, Inci I, Zhang YS, Khademhosseini A, Dokmeci MR. Bioinks for 3D bioprinting: An overview. Biomater Sci. 2018;6(5):915-46.

85. Evans CH, Huard J. Gene therapy approaches to regenerating the musculoskeletal system. Nat Rev Rheumatol [Internet]. 2015;11(4):234-42. Available from: http://dx.doi.org/10.1038/nrrheum.2015.28

86. Shafiee A, Atala A. Printing Technologies for Medical Applications. Trends Mol Med. 2016;22(3):254-65.

87. Kim M, Kim GH. 3D multi-layered fibrous cellulose structure using an electrohydrodynamic process for tissue engineering. J Colloid Interface Sci [Internet]. 2015;457:180-7. Available from: http://dx.doi.org/10.1016/j.jcis.2015.07.007

88. Yeo M, Kim G. Three-Dimensional Microfibrous Bundle Structure Fabricated Using an Electric Field-Assisted/Cell Printing Process for Muscle Tissue Regeneration. ACS Biomater Sci Eng. 2018;4(2):728-38.

89. Li Y, Poon CT, Li M, Lu TJ, Pingguan-Murphy B, Xu F. Chinese-noodle-inspired muscle myofiber fabrication. Adv Funct Mater. 2015;25(37):5999-6008.

90. Jung JW, Yi HG, Kang TY, Yong WJ, Jin S, Yun WS, et al. Evaluation of the effective diffusivity of a freeform fabricated scaffold using computational simulation. J Biomech Eng. 2013;135(8):1-7.

91. Bian W, Juhas M, Pfeiler TW, Bursac N. Local tissue geometry determines contractile force generation of engineered muscle networks. Tissue Eng - Part A. 2012;18(9-10):957-67. 
92. Guo X, Gonzalez M, Stancescu M, Vandenburgh HH, Hickman JJ. Neuromuscular junction formation between human stem cell-derived motoneurons and human skeletal muscle in a defined system. Biomaterials [Internet]. 2011;32(36):9602-11. Available from: http://dx.doi.org/10.1016/j.biomaterials.2011.09.014

93. Choi YJ, Kim TG, Jeong J, Yi HG, Park JW, Hwang W, et al. 3D Cell Printing of Functional Skeletal Muscle Constructs Using Skeletal Muscle-Derived Bioink. Adv Healthc Mater. 2016;5(20):2636-45.

94. Kim JH, Ko IK, Atala A, Yoo JJ. Progressive muscle cell delivery as a solution for volumetric muscle defect repair. Sci Rep [Internet]. 2016;6(June):1-13. Available from: http://dx.doi.org/10.1038/srep38754

95. Wu X, Corona BT, Chen X, Walters TJ. A standardized rat model of volumetric muscle loss injury for the development of tissue engineering therapies. Biores Open Access. 2012;1(6):280-90.

96. Novosel EC, Kleinhans C, Kluger PJ. Vascularization is the key challenge in tissue engineering. Adv Drug Deliv Rev [Internet]. 2011;63(4):300-11. Available from: http://dx.doi.org/10.1016/j.addr.2011.03.004

97. Jain RK, Au P, Tam J, Duda DG, Fukumura D. Engineering vascularized tissue. Nat Biotechnol. 2005;23(7):821-3.

98. Skardal A, Devarasetty M, Kang HW, Mead I, Bishop C, Shupe T, et al. A hydrogel bioink toolkit for mimicking native tissue biochemical and mechanical properties in bioprinted tissue constructs. Acta Biomater [Internet]. 2015;25:24-34. Available from: http://dx.doi.org/10.1016/j.actbio.2015.07.030

99. Laternser S, Keller H, Leupin O, Rausch M, Graf-Hausner U, Rimann M. A Novel Microplate 3D Bioprinting Platform for the Engineering of Muscle and Tendon Tissues. SLAS Technol. 2018;23(6):599-613.

100. Ashby, P. R., Wilson, S. J., \& Harris AJ. Formation of Primary and Secondary Myotubes in Aneural Muscles in the Mouse Mutant peroneal muscular atrophy. [Internet]. 1993. Available from: https://doi.org/10.1006/dbio.1993.1098 
101. Kang SB, Olson JL, Atala A, Yoo JJ. Functional recovery of completely denervated muscle: Implications for innervation of tissue-engineered muscle. Tissue Eng - Part A. 2012;18(1718):1912-20.

102. Dhawan V, Lytle IF, Dow DE, Huang YC, Brown DL. Neurotization improves contractile forces of tissue-engineered skeletal muscle. Tissue Eng. 2007;13(11):2813-21.

103. Kim JH, Kim I, Seol YJ, Ko IK, Yoo JJ, Atala A, et al. Neural cell integration into 3D bioprinted skeletal muscle constructs accelerates restoration of muscle function. Nat Commun [Internet]. 2020;11(1):1-12. Available from: http://dx.doi.org/10.1038/s41467020-14930-9

104. Atala A, Bauer SB, Soker S, Yoo JJ, Retik AB. Tissue-engineered autologous bladders for patients needing cystoplasty. Lancet. 2006;367(9518):1241-6.

105. Macchiarini P, Jungebluth P, Go T, Asnaghi MA, Rees LE, Cogan TA, et al. Clinical transplantation of a tissue-engineered airway. Lancet [Internet]. 2008;372(9655):2023-30. Available from: http://dx.doi.org/10.1016/S0140-6736(08)61598-6

106. Seol YJ, Kang HW, Lee SJ, Atala A, Yoo JJ. Bioprinting technology and its applications. Eur J Cardio-thoracic Surg. 2014;46(3):342-8.

107. Cui X, Gao G, Qiu Y. Accelerated myotube formation using bioprinting technology for biosensor applications. Biotechnol Lett. 2013;35(3):315-21.

108. Merceron TK, Burt M, Seol YJ, Kang HW, Lee SJ, Yoo JJ, et al. A 3D bioprinted complex structure for engineering the muscle-tendon unit. Biofabrication [Internet]. 2015;7(3):35003. Available from: http://dx.doi.org/10.1088/1758-5090/7/3/035003

109. Alraies MC, Eckman P. Adult heart transplant: Indications and outcomes. J Thorac Dis. 2014;6(8):1120-8.

110. Manji RA, Menkis AH, Ekser B, Cooper DKC. Porcine bioprosthetic heart valves: The next generation. Am Heart J [Internet]. 2012;164(2):177-85. Available from: http://dx.doi.org/10.1016/j.ahj.2012.05.011

111. Gilon D, Cape EG, Handschumacher MD, Song JK, Solheim J, VanAuker M, et al. Effect 
of three-dimensional valve shape on the hemodynamics of aortic stenosis: Threedimensional echocardiographic stereolithography and patient studies. J Am Coll Cardiol. 2002;40(8):1479-86.

112. Pati F, Jang J, Ha DH, Won Kim S, Rhie JW, Shim JH, et al. Printing three-dimensional tissue analogues with decellularized extracellular matrix bioink. Nat Commun [Internet]. 2014;5:1-11. Available from: http://dx.doi.org/10.1038/ncomms4935

113. Ong CS, Fukunishi T, Zhang H, Huang CY, Nashed A, Blazeski A, et al. Biomaterial-Free Three-Dimensional Bioprinting of Cardiac Tissue using Human Induced Pluripotent Stem Cell Derived Cardiomyocytes. Sci Rep. 2017;7(1):2-12.

114. Xu T, Baicu C, Aho M, Zile M, Boland T. Fabrication and characterization of bioengineered cardiac pseudo tissues. Biofabrication. 2009;1(3).

115. Wang Z, Abdulla R, Parker B, Samanipour R, Ghosh S, Kim K. A simple and highresolution stereolithography-based 3D bioprinting system using visible light crosslinkable bioinks. Biofabrication [Internet]. 2015;7(4):45009. Available from: http://dx.doi.org/10.1088/1758-5090/7/4/045009

116. Malda J, Visser J, Melchels FP, Jüngst T, Hennink WE, Dhert WJA, et al. 25th anniversary article: Engineering hydrogels for biofabrication. Adv Mater. 2013;25(36):5011-28.

117. Gaudino M, Benedetto U, Fremes S, Biondi-Zoccai G, Sedrakyan A, Puskas JD, et al. Radial-Artery or Saphenous-Vein Grafts in Coronary-Artery Bypass Surgery. N Engl J Med. 2018;378(22):2069-77.

118. Ozbolat IT, Moncal KK, Gudapati H. Evaluation of bioprinter technologies. Addit Manuf [Internet]. 2017;13:179-200. Available from: http://dx.doi.org/10.1016/j.addma.2016.10.003

119. Aversa Z, Costelli P, Muscaritoli M, Argilés JM, Busquets S, Stemmler B, et al. Threedimensional printing for cardiovascular diseases: From anatomical modeling to dynamic functionality. Adv Healthc Mater [Internet]. 2018;7(1):1-14. Available from: https://doi.org/10.1016/j.bjps.2017.12.006

120. Cui H, Nowicki M, Fisher JP, Zhang LG. 3D Bioprinting for Organ Regeneration. Adv 
Healthc Mater. 2017;6(1).

121. Hann SY, Cui H, Esworthy T, Miao S, Zhou X, Lee S jun, et al. Recent advances in 3D printing: vascular network for tissue and organ regeneration. Transl Res [Internet]. 2019;211:46-63. Available from: https://doi.org/10.1016/j.trs1.2019.04.002

122. Cui H, Zhu W, Huang Y, Liu C, Yu ZX, Nowicki M, et al. In vitro and in vivo evaluation of $3 \mathrm{D}$ bioprinted small-diameter vasculature with smooth muscle and endothelium. Biofabrication. 2020;12(1).

123. Shadrin IY, Khodabukus A, Bursac N. Striated muscle function, regeneration, and repair. Cell Mol Life Sci. 2016;73(22):4175-202.

124. Fuoco C, Cannata S, Gargioli C. Could a functional artificial skeletal muscle be useful in muscle wasting? Curr Opin Clin Nutr Metab Care. 2016;19(3):182-7.

125. Kang HW, Lee SJ, Ko IK, Kengla C, Yoo JJ, Atala A. A 3D bioprinting system to produce human-scale tissue constructs with structural integrity. Nat Biotechnol [Internet]. 2016;34(3):312-9. Available from: http://dx.doi.org/10.1038/nbt.3413

126. Kim JH, Yoo JJ, Lee SJ. Three-dimensional cell-based bioprinting for soft tissue regeneration. Tissue Eng Regen Med. 2016;13(6):647-62.

127. Mironov V, Kasyanov V, Drake C, Markwald RR. Organ printing: Promises and challenges. Regen Med. 2008;3(1):93-103.

128. Zhuang P, An J, Chua CK, Tan LP. Bioprinting of 3D in vitro skeletal muscle models: A review. Mater Des [Internet]. 2020;193:108794. Available from: https://doi.org/10.1016/j.matdes.2020.108794 